\title{
Soil Nitrogen Availability in Tallgrass Prairie Under the Fire-Grazing Interaction
}

\author{
R. H. Anderson, ${ }^{1}$ Samuel D. Fublendorf, ${ }^{2}$ and David M. Engle ${ }^{3}$ \\ Authors are ${ }^{1}$ Graduate Assistant, ${ }^{2}$ Professor, and ${ }^{3}$ Regents Professor of Rangeland Ecology and Management, \\ Department of Plant and Soil Sciences, Oklahoma State University, 368 AGH, Stillwater, OK 74078-6028.
}

\begin{abstract}
Fire and grazing are interactive disturbance processes that are important to the structure and function of grassland ecosystems. Studies of nitrogen $(\mathrm{N})$ availability report different effects following grazing and fire. However, these studies have largely neglected the spatially controlled interaction between fire and grazing. The objective of our work was to evaluate an application of the fire-grazing interaction model on $\mathrm{N}$ availability in a tallgrass prairie. We compared patches within a shifting mosaic landscape where each patch varied in time since focal disturbance (fire and intense grazing disturbance). We also evaluated $\mathrm{N}$ availability on a burned and grazed landscape where fires and moderate grazing occurred annually and uniformly across the entire landscape. These treatments were both burned and grazed where the only difference was spatial and temporal variability in fire application and grazing disturbance. Samples were collected from upland sites in May of 2003 and 2004. Total soil inorganic $\mathrm{N}\left(\mathrm{NH}_{4}{ }^{+}-\mathrm{N}+\mathrm{NO}_{3}{ }^{-}-\mathrm{N}\right)$ and a growth chamber experiment with hard red winter wheat (Triticum aestivum $\mathrm{L}$. cv. Jagger) were used to evaluate potential $\mathrm{N}$ availability. Our study produced patterns of $\mathrm{N}$ availability that are more similar to studies of grazing lawns where $\mathrm{N}$ availability is enhanced by focal grazing than from studies of fire without grazing. Overall, our study demonstrates that fire and grazing are interactive. Unburned patches have minimal grazing pressure and low $\mathrm{N}$ availability. Fire-grazing interaction may provide a management alternative that enables sustainable livestock production, through increased carrying capacity in focally disturbed patches, concomitant with biological diversity in tallgrass prairie.
\end{abstract}

\section{Resumen}

El fuego y el apacentamiento son procesos interactivos de disturbio que son importantes para la estructura y funcionamiento de los ecosistemas de pastizal. Los estudios de disponibilidad de nitrógeno $(\mathrm{N})$ reportan diferentes efectos después del apacentamiento y el fuego. Sin embargo, estos estudios en gran parte han negado la interacción espacialmente controlada entre el fuego y el apacentamiento. El objetivo de nuestro trabajo fue evaluar una aplicación del modelo de interacción fuegoapacentamiento sobre la disponibilidad de $\mathrm{N}$ en una pradera de zacates altos. Compramos parches dentro de un paisaje de mosaicos cambiantes, donde cada parche varió en tiempo por el disturbio focal (disturbio de fuego y apacentamiento intenso). También evaluamos la disponibilidad de $\mathrm{N}$ en un paisaje quemado y apacentado, donde los fuegos y el apacentamiento moderado ocurren anualmente y uniformemente a través de todo el paisaje. Estos tratamientos fueron tanto quemados y apacentados donde la única diferencia fue espacial y la variabilidad temporal en la aplicación del fuego y disturbio de apacentamiento. Las muestras fueron colectadas de mesetas en Mayo del 2003 y 2004. El N inorgánico total del suelo $\left(\mathrm{NH}_{4}{ }^{+}-\mathrm{N}+\mathrm{NO}_{3}{ }^{-}-\mathrm{N}\right)$ y un experimento en cámara de crecimiento con trigo rojo invernal (Triticum aestivum L. cv. Jagger) fueron usados para evaluar la disponibilidad potencial de N. Nuestro estudio produjo patrones de disponibilidad de N que son más similares a los estudios de apacentamiento de praderas, donde la disponibilidad de $\mathrm{N}$ es aumentada por el apacentamiento focal, que a los de estudios de fuego sin apacentamiento. En general, nuestro estudio demuestra que el fuego y el apacentamiento son interactivos. Los parches sin quemar tienen una presión de apacentamiento mínima y una baja disponibilidad de N. La interacción fuego-apacentamiento pude proveer una alternativa de manejo que permite la producción sustentable de ganado, por medio de un aumento de la capacidad de carga en los parches focalmente disturbados, concomitante con la diversidad biológica de las praderas de zacates altos.

Key Words: shifting mosaic, grazing, herbivory, $\mathrm{N}$ availability, net $\mathrm{N}$ mineralization

\section{INTRODUCTION}

This research was funded by the Oklahoma Agricultural Experiment Station, The Nature Conservancy, and the National Research Initiative of the USDA Cooperative State Research, Education and Extension Service, grant 2003-35101-12928.

Correspondence: S. D. Fuhlendorf, Dept of Plant and Soil Sciences, Oklahoma State University, 368 AGH, Stillwater, OK 74078-6028. Email: sam.fuhlendorf@okstate.edu

Current address: David M. Engle, Professor and Chair, Dept of Natural Resource Ecology and Management, 339 Science II, lowa State University, Ames, IA 50011-3221.

Manuscript received 6 November 2005; manuscript accepted 15 July 2006.
Sustainable management and conservation of ecosystems requires an understanding of temporal and spatial variability (Fuhlendorf and Engle 2001, 2004). Variability in ecosystem structure and function can be caused by spatiotemporal patterns of resource availability and by variable patterns of disturbance. In grassland ecosystems, fire and grazing are 2 primary disturbance processes (McNaughton et al. 1988; Collins 1990, 2000; Knapp et al. 1999), and soil nitrogen (N) is frequently a resource that affects the productivity and 


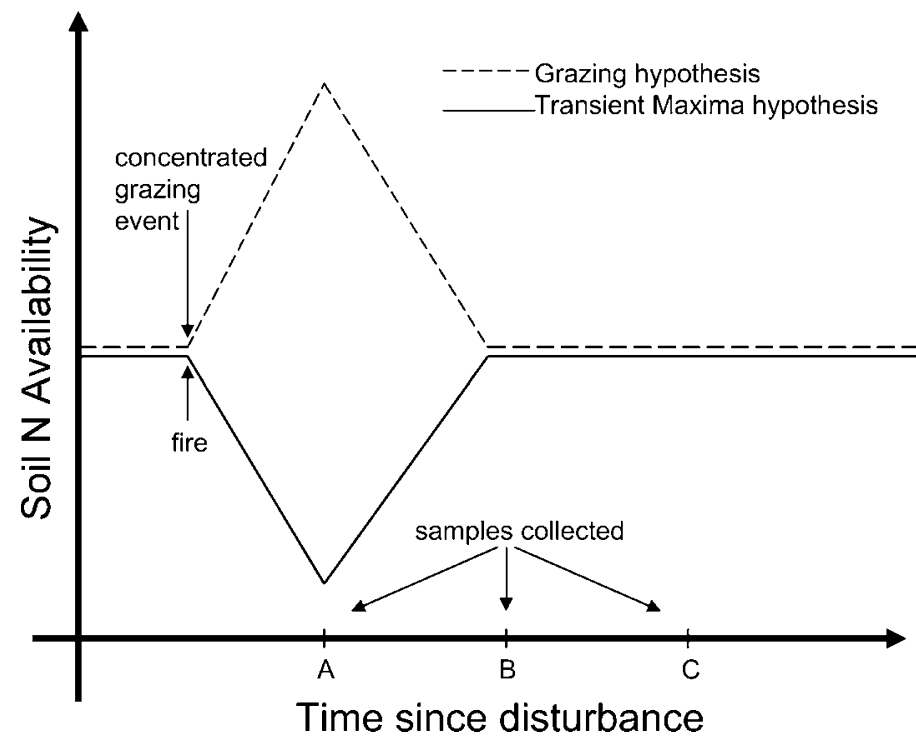

Figure 1. Conceptual model of the temporal dynamics of soil $\mathrm{N}$ availability in response to fire: Transient Maxima hypothesis (Seastedt et al. 1991; Seastedt and Knapp 1993; Blair 1997) and grazing: Grazing hypothesis (McNaughton 1984; McNaughton et al. 1997; Ruess and McNaughton 1987; Seagle et al. 1992). Samples were collected in May 2003 and 2004 from patches recently disturbed by focal fire and grazing (A), 1 year since focal disturbance (B), and 2 years since focal disturbance (C). The effect of disturbance is a combined interactive effect of localized fire followed by focal grazing and the formation of a grazing lawn (Fuhlendorf and Engle 2001).

composition of vegetation (Tilman 1987; Milchunas and Lauenroth 1995; Maron and Jeffries 2001; Augustine et al. 2003). Most studies of fire and grazing on $\mathrm{N}$ availability have focused on the main effects of each disturbance but have largely neglected their interaction in space and time, which may have been an important evolutionary mechanism shaping grassland landscapes and providing habitat for many species (Fuhlendorf and Engle 2001). Therefore, studies of the patterns of $\mathrm{N}$ availability associated with the fire-grazing interaction are needed to more fully understand the structure and function of grassland ecosystems.

The interaction between fire and grazing is organized by positive and negative feedbacks that produce spatial and temporal variability across the landscape and has been described as a shifting mosaic (Fuhlendorf and Engle 2001, 2004). The probability of fire occurring is highest on an undisturbed grassland because of the accumulation of litter and standing biomass that can serve as fine fuel. Grazing animals avoid this undisturbed prairie when recently burned or grazed communities are available. When a fire occurs and fuel is consumed, there is an increase in forage productivity, palatability, and accessibility on the burned area. Thus, grazing animals are attracted, increasing the probability and intensity of grazing on the recently burned area. Focal grazing lowers fuel levels and reduces the probability and intensity of fire (Steuter et al. 1995; Hobbs 1996). Grazing animals will congregate on recently burned patches until fires occur in other locations, which will attract them to other areas and allow recovery of original focally disturbed patches. As grasses regain dominance and litter accumulates over the next several years, the probability of fire increases. The result is a mosaic of patches that are recently burned and focally grazed nested within a landscape that is variable in time since focal fire and grazing. So, the landscape includes patches that are intensively disturbed and undisturbed and many levels of recovery, and all patches are dependent on the condition of surrounding patches.

Nitrogen limitations are common in grasslands (Blair 1997; Augustine et al. 2003) and can have a large effect on the behavior and productivity of domestic and wild ungulates (Augustine and Frank 2001). For example, focal grazing by native large ungulates in the Serengeti and Yellowstone National Park has resulted in greater plant productivity from $\mathrm{N}$ enrichment on the resulting grazing lawn (area of focused grazing where vegetation is maintained at a low stature by herding animals) (McNaughton 1984; McNaughton et al. 1988; Frank and McNaughton 1992). Nitrogen enrichment has been reported within grazing lawns and has even been proposed as the mechanism by which native African ungulates have evolved on N-limited grasslands (McNaughton 1984; Ruess and McNaughton 1987; Seagle et al. 1992; McNaughton et al. 1997). In fact, greater $N$ mineralization within grazing lawns has been reported from numerous studies conducted across a variety of grassland ecosystems (Risser and Parton 1982; Frank and McNaughton 1993; Frank and Evans 1997; Tracy and Frank 1998; Johnson and Matchett 2001; Augustine et al. 2003). This has the potential to contribute to sustainable livestock production because a major challenge to domestic livestock enterprises that are based on native grasslands is protein and $\mathrm{N}$ limitations in forage (Mattson 1980). Relationships between grazing and $\mathrm{N}$ availability have been investigated but remains largely unevaluated in the context of fire-grazing interaction.

Fire is a common disturbance on grasslands that can also influence $\mathrm{N}$ availability. In the absence of large ungulate grazing, annual burning has reduced net $\mathrm{N}$ mineralization (Blair 1997; Turner et al. 1997; Fynn et al. 2003), thus promoting $\mathrm{N}$ limitation and immobilization of existing soil inorganic $\mathrm{N}$ from turnover of lower-quality (i.e., higher C: $\mathrm{N}$ ratio) organic matter (Ojima et al. 1994; Johnson and Matchett 2001; Fynn et al. 2003). However, infrequent fire allows accumulation of litter that can lead to limitations in productivity from light and temperature constraints. Immediately following fire, productivity becomes limited by $\mathrm{N}$ availability as plant growth increases (Seastedt et al. 1991; Seastedt and Knapp 1993). The Transient Maxima hypothesis suggests that this episodic release from light limitations to $\mathrm{N}$ limitations results in a temporary surge in overall grassland productivity (Seastedt and Knapp 1993). The resulting pattern of $\mathrm{N}$ availability is an initial decline immediately following fire and the eventual recovery of available $\mathrm{N}$ as light becomes limited once again (Seastedt et al. 1991; Seastedt and Knapp 1993; Blair 1997).

Fire and grazing are important disturbances in many grassland ecosystems regulating $\mathrm{N}$ availability, but most studies have focused on the main effects of fire and grazing with little attention given to their ecological interaction in space and time. Studies of the main effect of fire and grazing have generated different hypotheses describing $\mathrm{N}$ availability following each independent disturbance (Fig. 1). We have developed an experiment capable of evaluating the spatial and temporal 
interaction of fire and grazing on grassland structure and function (Fuhlendorf and Engle 2001, 2004) and evaluate a pair of competing hypotheses. For this study, we specifically tested whether $\mathrm{N}$ availability under a fire-grazing interaction was more accurately modeled by either of 2 competing hypotheses of the effects of fire and grazing independent of the other disturbance. The Grazing hypothesis (sample A > samples B and C; Fig. 1) predicts an increase in $\mathrm{N}$ availability followed by a gradual decline in response to concentrated grazing pressure (McNaughton 1984; Ruess and McNaughton 1987; Seagle et al. 1992; McNaughton et al. 1997). On the other hand, the Transient Maxima hypothesis (sample A $<$ samples B and C; Fig. 1) predicts that $\mathrm{N}$ availability will decrease immediately following fire and gradually increase over the next few years as light becomes limited once again (Seastedt et al. 1991; Seastedt and Knapp 1993; Blair 1997). To evaluate these competing hypotheses, we evaluated $\mathrm{N}$ availability on patches within a shifting mosaic landscape where each patch varied in time since focal fire and grazing disturbance. We also evaluated $\mathrm{N}$ availability on a landscape that had similar grazing pressure to the shifting mosaic landscape but where the entire area was burned annually and the fire-grazing interaction did not exist as a spatial interaction where grazing animals could select from burned and unburned patches. So, we have 2 treatments that are both burned and grazed, but the only difference is the spatial and temporal patterns of fire and grazing.

\section{MATERIALS AND METHODS}

\section{Study Area}

Our study was conducted on the Nature Conservancy's 16 000-ha Tallgrass Prairie Preserve (TGPP) located in northeastern Oklahoma at the southern edge of the Flint Hills in the tallgrass prairie region of central North America. Mean annual precipitation of the region is $870 \mathrm{~mm}$ with $70 \%$ occurring between April and September (Bourlier et al. 1979). Vegetation at the TGPP is dominated by C4 grasses big bluestem (Andropogon gerardii Vitman), Indian grass (Sorghastrum nutans [L.] Nash), switchgrass (Panicum virgatum L.), and little bluestem (Schizachyrium scoparium [Michx.] Nash) (Diggs et al. 1999). Topography is gently rolling with soils derived from shale, limestone, and sandstone. Limestone is typically found interbedded between sandstone and shale with sandstone found at the surface of ridge crests. Either shale or limestone can be found as outcrops on side slopes or toe slopes as a result of geologic erosion. The result is a heterogeneous mixture of soils over multiple scales that vary in texture depending on parent material and topographic position. Site descriptions contain complexes of thermic lithic Haplustolls and thermic aquic Paleustalfs (Bourlier et al. 1979). Upland sites contain mollic epipedons characteristic of long-term grassland vegetation and possess smectitic mineralogy. We limited our evaluations of $\mathrm{N}$ availability to upland soils.

\section{Experimental Design}

To evaluate the effects of the ecological interaction of fire and grazing on $\mathrm{N}$ availability, 2 contrasting fire-grazing regimes were evaluated each with 2 replications (pastures) arranged in a completely randomized design. A shifting mosaic fire-grazing regime has fire applied to spatially discrete patches within a larger area (approximately $1200 \mathrm{ha}$ ) that is unburned. Fires were annually applied to one-third of the landscape on a 3-year return interval, while grazing intensity was calculated for the entire area. Alternatively, a homogeneous fire-grazing regime was burned in its entirety each year (also approximately 1200 ha). These different fire-grazing regimes were stocked with yearling steers (Bos taurus) similarly, but previous analyses demonstrated that these grazing animals spend over $70 \%$ of their grazing time on recently burned patches and the majority of the remaining time on patches burned 1 year earlier avoiding most patches burned 2 years earlier (Fuhlendorf and Engle 2004). So, grazing pressure in the shifting mosaic fire-grazing regime varied from 2 to 3 times greater than the homogeneous fire-grazing regime on recently burned patches to unburned patches that were essentially ungrazed. Specifically, soil samples were collected from georeferenced 0.5-ha sampling stations located on similar upland topo-edaphic landscape sites. One sampling station was located in each "years since focal disturbance" (YSFD) patch within the shifting mosaic firegrazing regime. In addition, we sampled from 2 similar sampling stations within the homogeneous fire-grazing regime where fire occurs annually but annual grazing pressure was moderate. All burns included in this study were conducted just prior to the growing season in March. Cattle were stocked in patch treatment pastures from mid-April through mid-July at a rate of $1.2 \mathrm{ha} / 270-\mathrm{kg}$ steer.

\section{Soil N Measurements}

To evaluate $\mathrm{N}$ availability, approximately $60-70$ soil samples were taken to a depth of $10 \mathrm{~cm}$ using a $1.9-\mathrm{cm}$-diameter soil core and bulked from each experimental area in May 2003 and 2004. If needed, litter was removed to sample mineral soil only, and direct sampling of fecal pats was avoided. Total soil inorganic $\mathrm{N}\left(\mathrm{NH}_{4}{ }^{+}-\mathrm{N}+\mathrm{NO}_{3}{ }^{-}-\mathrm{N}\right)$ was measured, immediately after sampling, in each year colorimetrically using a Lachat Quickchem Autoanalyzer (Milwaukee, WI) after extraction of $10 \mathrm{~g}$ of oven-dried soil with $100 \mathrm{ml}$ of $1 \mathrm{~mol} \cdot \mathrm{L}^{-1} \mathrm{KCl}$ solution (Mulvaney 1996). Potential $\mathrm{N}$ availability through the growing season was determined by a growth chamber experiment conducted in each year as a surrogate of net $\mathrm{N}$ mineralization (Fynn et al. 2003). Four air-dried 500-g subsamples from each homogenized composite sample were hand ground and placed into $0.95-\mathrm{L}$ polystyrene containers. Seven seeds of certified hard red winter wheat (Triticum aestivum L. cv. Jagger) were planted in each container. Hard red winter wheat was selected because of its known response to additions of $\mathrm{N}$ (Oscarson et al. 1995). We recognize that this is a C3 plant, and we are testing a C4dominated grassland soil, but our intent was to use a species sensitive to $\mathrm{N}$ limitations and use that species as a bioassay across all treatments. Five plants in each container were allowed to germinate and grow with optimal watering for 70 days with 18 hours of light per day at $25^{\circ} \mathrm{C}$ (Goncalves and Carlyle 1994). Half of the subsamples in each year received a basal dressing of a nutrient solution that contained macro ( $P$, $\mathrm{K}, \mathrm{Ca}, \mathrm{Mg}, \mathrm{S})$ and micro ( $\mathrm{Zn}, \mathrm{Cu}, \mathrm{Mn}, \mathrm{Fe}, \mathrm{B}$ and $\mathrm{Mo}$ ) nutrient elements to isolate the previously described $\mathrm{N}$ limitations in grasslands (Tilman 1987; Milchunas and Lauenroth 1995; Maron and Jeffries 2001; Augustine et al. 2003). Only half of 

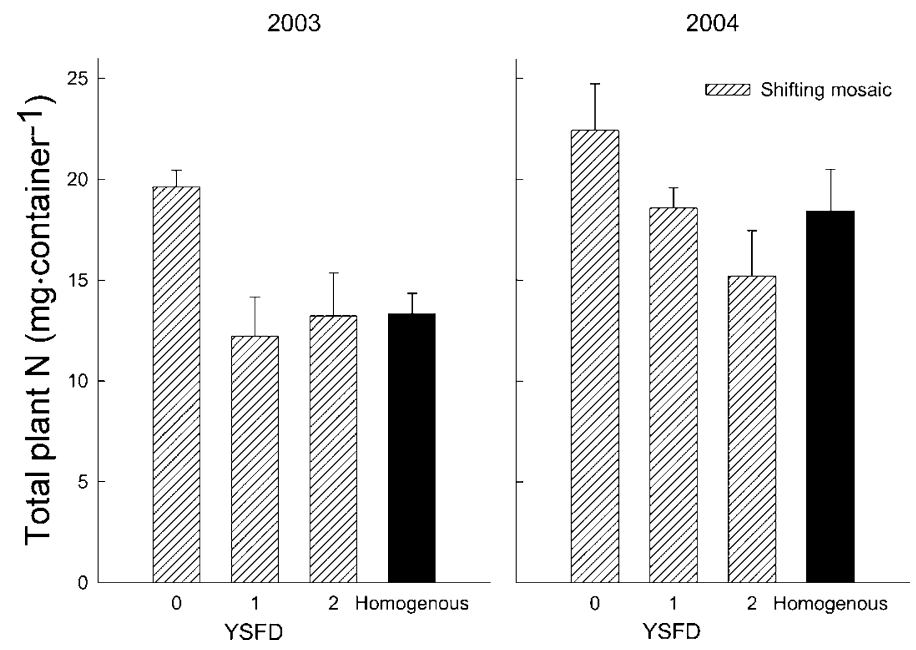

Figure 2. Total plant $N$ (roots + shoots) recovered from a growth chamber experiment using hard red winter wheat (Triticum aestivum L. CV. Jagger) as affected by a homogeneous fire-grazing regime and patches within a shifting mosaic fire-grazing regime. Patches were recently disturbed by focal fire and grazing, 1 year since focal disturbance (YSFD), and 2 years since focal disturbance. Histogram bars are least squares means $( \pm 1 \mathrm{SE})$.

the subsamples received the solution to preserve the study in the event of nutrient toxicity. The nutrient solution was initially supplied to bring the containers to field capacity and was also supplied halfway through the growing period. Subsamples were randomized within the growth chamber to prevent bias dependent on the location within the growth chamber. At the end of the 70-day growing period, roots and shoots from each container were harvested, dried for 7 days at $45^{\circ} \mathrm{C}$, and weighed (Ostertag and Hobbie 1999). Tissue N (\%) was determined by dry combustion with a Leco CN 2000 autoanalyzer (St Joseph, MI) and plant N (mg per container) was determined as the product of dry-weight biomass (g) and tissue $\mathrm{N}(\%)$. The recovered total (roots + shoots) plant $\mathrm{N}$ from each container was used as a metric of net $\mathrm{N}$ mineralized over the 70-day trial (Fynn et al. 2003). The relative change in total plant N from 2003 to 2004 was also computed to illustrate differences between years and to determine the relative influence of spatial variability as time since focal disturbance was different in each year for the same site within the shifting mosaic fire-grazing regime. Other methods of estimating net $\mathrm{N}$ mineralization are available through approaches such as the use of resin bags and laboratory incubations, but preliminary analysis indicated that these approaches were not as effective as the bioassay for our objectives. The bioassay is an efficient approach that allows an $\mathrm{N}$-sensitive plant to demonstrate differences in potential $\mathrm{N}$ availability over a given time period (Fynn et al. 2003).

\section{Data Analyses}

Each YSFD patch within the replicated shifting mosaic firegrazing regime and the similar sites sampled within the replicated homogeneous fire-grazing regime were analyzed as separate levels of the same main effect, which will be referred to as treatment. Both total soil inorganic $\mathrm{N}$ and total plant $\mathrm{N}$ data were analyzed in each year separately. Total plant $\mathrm{N}$ data were analyzed for interaction by a 2-way analysis of variance (ANOVA) where treatment and nutrient application were both main effects. There was no statistical interaction $(P>0.10)$ in either year, so data were combined in both years to better evaluate treatment effects on potential $\mathrm{N}$ availability. Significant differences among treatment means for total soil inorganic $\mathrm{N}$ data, total plant $\mathrm{N}$ data, and the relative change in total plant $\mathrm{N}$ from 2003 to 2004 were independently tested using single degree of freedom contrasts in ANOVA. Because of the extent of our study site and the small number of degrees of freedom, $F$ values were considered significant at $P<0.10$ throughout this paper. All analyses were conducted in SAS/STAT (1989).

\section{RESULTS}

Total soil inorganic $\mathrm{N}$ at the time of sampling was not significantly different across treatments for either year. However, potential $\mathrm{N}$ availability (as indicated by the bioassay) was strongly influenced by treatment and highest in the most recently burned and grazed patch in the shifting mosaic treatment. There was no statistical interaction between treatment and nutrient application for total plant $\mathrm{N}$ recovered across all subsamples in either $2003(P=0.3)$ or 2004 $(P=0.9)$ trials. So, total plant $\mathrm{N}$ was combined across subsamples to evaluate treatment effects to provide an indication of $\mathrm{N}$ availability throughout the growing period. Root and shoot biomass varied in a similar manner to total plant $\mathrm{N}$, while the concentration of tissue $\mathrm{N}$ did not vary much with treatment (data not shown). In 2003 and 2004, the focally disturbed patch produced containers with the greatest total plant $\mathrm{N}$ (Fig. 2). This pattern was observed both years in spite of the fact that time since focal disturbance shifted between years resulting in different patches following similar patterns across years (Table 1 ).

Change in total plant N from 2003 to 2004 (Fig. 3) from each experimental area indicates change in net $\mathrm{N}$ mineralization from one year to the next relative to change in year since focal disturbance. So, the relative change is a stronger indication of the treatment effect than data from each year because it reflects the change that occurred on an individual sample site that is associated with a specific treatment. The patch within the shifting mosaic regime focally disturbed between 2003 and 2004 sampling had the greatest increase (Fig. 3), indicating significantly greater net $\mathrm{N}$ mineralization following focal fire and grazing disturbance than all other sites (Table 1). Patches that were 1 or 2 years since focal disturbance within the shifting mosaic regime had the lowest change, while the homogeneous regime increased by $27 \%$ but was still significantly less than the increase from the patch burned and focally grazed between years.

\section{DISCUSSION}

Fire and grazing have long been recognized as dominant forces regulating the structure and function of grassland ecosystems. The main effects of these disturbances on $\mathrm{N}$ dynamics have been described with competing hypotheses, while the spatially controlled interaction has largely been neglected (Fig. 1), 
Table 1. Fand $P$ values for total soil inorganic $\mathrm{N}$ and total plant $\mathrm{N}$ among treatments and years since focal disturbance (YSFD) in the shifting mosaic treatment. $^{1}$

\begin{tabular}{|c|c|c|c|c|c|c|c|c|c|c|}
\hline & \multicolumn{4}{|c|}{2003} & \multicolumn{4}{|c|}{2004} & \multirow{2}{*}{\multicolumn{2}{|c|}{$\begin{array}{c}\text { Change in total plant } N \\
\text { across years }\end{array}$}} \\
\hline & \multicolumn{2}{|c|}{ Total soil inorganic $\mathrm{N}$} & \multicolumn{2}{|c|}{ Total plant N } & \multicolumn{2}{|c|}{ Total soil inorganic $\mathrm{N}$} & \multicolumn{2}{|c|}{ Total plant N } & & \\
\hline & $F_{1,4}$ & $P$ & $F_{1,12}$ & $P$ & $F_{1,4}$ & $P$ & $F_{1,12}$ & $P$ & $F_{1,12}$ & $P$ \\
\hline OYSFD vs. 1 YSFD & 0.59 & ns & 10.94 & 0.006 & 0.46 & ns & 1.89 & ns & 20.00 & $<0.001$ \\
\hline OYSFD vs. 2 YSFD & 2.88 & ns & 8.13 & 0.015 & 0.02 & ns & 6.61 & 0.025 & 7.25 & 0.019 \\
\hline OYSFD vs. homogenous & 3.98 & ns & 7.87 & 0.016 & 1.78 & ns & 2.03 & ns & 3.18 & 0.099 \\
\hline 1YSFD vs. 2YSFD & 0.87 & ns & 0.21 & ns & 0.65 & ns & 1.43 & ns & 3.17 & ns \\
\hline 1YSFD vs. homogenous & 1.51 & ns & 0.25 & ns & 4.04 & ns & 0.01 & ns & 7.23 & 0.019 \\
\hline 2YSFD vs. homogenous & 0.09 & ns & 0.01 & ns & 1.46 & ns & 1.32 & ns & 0.83 & ns \\
\hline
\end{tabular}

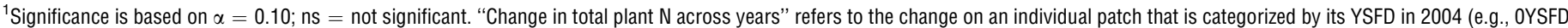
in 2003 becomes 1YSFD in 2004, 1YSFD in 2003 becomes 2YSFD in 2004).

suggesting a potential conflict in understanding the interactive effect of the fire-grazing shifting mosaic. We found that the fire-grazing interaction leads to increased $\mathrm{N}$ availability that is consistent with the Grazing model (Fig. 1) (McNaughton 1984; Ruess and McNaughton 1987; Seagle et al. 1992; McNaughton et al. 1997), where $\mathrm{N}$ availability is highest on patches that have been focally disturbed with fire and severe grazing pressure (Fig. 2). Grazing pressure on the focally disturbed patches was approximately 3 times that of the uniform grazing.

Differences between our fire-grazing regimes are characterized by fire frequency and spatiotemporal patterns of the current year's grazing intensity between treatments and among patches within the shifting mosaic treatment. The most recently burned patches within the shifting mosaic fire-grazing regime are most heavily grazed, whereas grazing pressure within the homogeneous fire-grazing regime is more uniformly distributed throughout the landscape and grazing lawns are less likely to occur. In fact, the application of traditional homogeneous management is often employed specifically to minimize the creation of grazing lawns that are promoted by the shifting mosaic approach. In general, focally disturbed patches (grazing lawns) were found to contain greater potential $\mathrm{N}$ availability relative to previously burned patches and the homogeneous fire-grazing regime, respectively. Furthermore, treatment patterns were consistent between years and through the analysis of change from year to year. Thus, our results indicate that the shifting mosaic treatment consists of $\mathrm{N}$-enriched patches that are recently burned and focally grazed nested within an unburned and ungrazed landscape. Our study demonstrates that the fire-grazing interaction produces patterns of potential $\mathrm{N}$ availability that are more similar to grazing lawn studies (Figs. 1-3) where potential $\mathrm{N}$ availability is enhanced by periodic focal grazing (McNaughton 1984; Ruess and McNaughton 1987; Seagle et al. 1992; McNaughton et al. 1997). Potential $\mathrm{N}$ availability in an annually burned and homogeneously grazed regime is influenced more by interannual variability.

Grazing is a keystone disturbance process in grasslands that can influence the amount of $\mathrm{N}$ available to growing plants. Studies have commonly reported $\mathrm{C}$ translocation from roots to shoots following defoliation (Detling et al. 1979; Caldwell et al. 1981; Osterheld and McNaughton 1988), which could potentially alter the C:N ratio of senesced roots during decomposition regulating mineralization-immobilization dynamics
(Schimel and Parton 1986; Parton et al. 1987). Other studies, including a comprehensive meta-analysis, have reported no decline in belowground primary productivity in grasslands with a long evolutionary history of grazing in response to periodic defoliation (Milchunas and Lauenroth 1993; McNaughton et al. 1998). However, grazing patterns in these studies differ from the effects of the focal grazing that occurs under a shifting

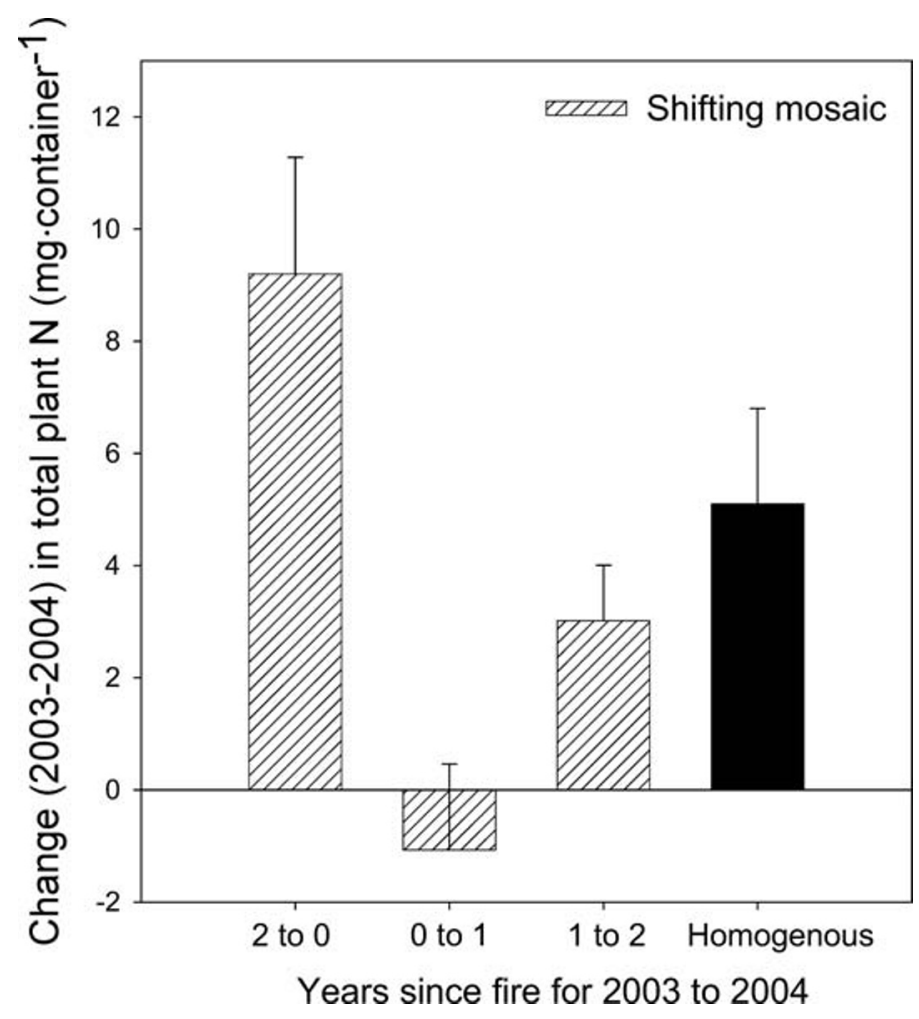

Figure 3. Relative change in total plant N (roots and shoots) recovered from a growth chamber experiment using hard red winter wheat (Triticum aestivum L. Cv. Jagger) as affected by a homogeneous firegrazing regime and patches within a shifting mosaic fire-grazing regime. Patches were disturbed by focal fire and grazing in the present year, 1 year since focal disturbance (YSFD), and 2 years since focal disturbance. Histogram bars are least squares means ( $\pm 1 \mathrm{SE})$. Change in total plant $\mathrm{N}$ across years refers to the change on an individual patch that is categorized by its YSFD in 2004 (e.g., OYSFD in 2003 becomes 1YSFD in 2004, 1YSFD in 2003 becomes 2YSFD in 2004). 
mosaic fire-grazing regime. Intense defoliation on grazing lawns may impede belowground $\mathrm{C}$ inputs to heterotrophs and alter decomposition rates (Johnson and Matchett 2001; Sankaran and Augustine 2004). There is an apparent feedback that exists between $\mathrm{N}$ availability and grazing activity moderated through decomposition (McNaughton et al. 1997; Augustine et al. 2003), but the degree to which intensity and duration of grazing influences $\mathrm{N}$ availability is not well understood. The most conspicuous effects of grazing on turnover rates of $\mathrm{N}$ are 1) redistribution of $\mathrm{N}$ in aboveground vegetation into inorganic N-containing excrement (Ruess and McNaughton 1987; Frank et al. 1994) and 2) imposing feedbacks between feces and microbial activity that facilitates net $\mathrm{N}$ mineralization surrounding the affected microsite (Risser and Parton 1982; Ruess and McNaughton 1987; McNaughton et al. 1988; Seagle et al. 1992; Frank and McNaughton 1993; Frank and Evans 1997; Tracy and Frank 1998). Uncoupling the relative contributions of urine, dung, and grazer-modified substrate availability to determine the actual causal mechanism behind the observed pulse in $\mathrm{N}$ availability is a challenge and merits specific studies designed to test alternative hypotheses.

Long-term annual burning causes a reduction in $\mathrm{N}$ availability of ungrazed prairie (Ojima et al. 1994; Blair 1997; Turner et al. 1997; Fynn et al. 2003). There has been less research on the effects of annual burning followed by moderate to heavy grazing. Grazing in an annually burned tallgrass prairie maintains root tissue quality (i.e., lower $\mathrm{C}: \mathrm{N}$ ) as vegetation allocate less $\mathrm{C}$ to belowground roots and rhizomes in response to repeated defoliation relative to annually burned prairie alone (Johnson and Matchett 2001). Thus, grazing activity seemingly acts as a buffer against declines in potential $\mathrm{N}$ availability commonly observed in annually burned grasslands. In our study we could not identify any reduction in $\mathrm{N}$ availability associated with annual burning and moderate uniform grazing within the homogeneous fire-grazing regime relative to other infrequently burned sites, but we did document greater $\mathrm{N}$ availability associated with the focal fire-grazing interaction.

\section{MANAGEMENT IMPLICATIONS}

Annual spring burning followed by spring and early summer grazing is a livestock enterprise system common in the tallgrass prairie region of central North America. Livestock ranchers employ annual spring burning as a means to uniformly distribute grazing pressure in order to achieve more efficient forage utilization when dominant tallgrasses are preferred forage. Tallgrasses are more productive, fire-tolerant, warmseason forage species that have a competitive advantage over less productive species when annually burned in spring (Seastedt et al. 1991; Towne and Kemp 2003). However, long-term annual burning may have contributed to loss of grassland obligate species diversity (Collins and Steinauer 1998; Jansen et al. 1999; Fuhlendorf et al. 2006). Unlike this traditional management, a patch rotation of localized fires concentrate livestock on postburn regrowth (i.e., fire-grazing interaction), maximizing livestock distribution over several years but minimizing distribution within individual years (Fuhlendorf and Engle 2004). Periodic deferment from fire and focal grazing under this management regime allows the accumulation of detritus in unburned patches and has resulted in increases in heterogeneity of plant communities in grassland landscapes (Fuhlendorf and Engle 2004). Increased heterogeneity results in increases in bird diversity by providing habitat for species that require intense disturbances and no disturbance within the same pasture (Fuhlendorf et al. 2006). In addition, a shifting mosaic application of the fire-grazing model seemingly enhances forage quality, at least partially from the increased $\mathrm{N}$ availability in the focally disturbed patch observed in the current study (McNaughton et al. 1988; Frank and McNaughton 1992). Application of the fire-grazing interaction provides a management alternative that seems to enable sustainable livestock production concomitant with conservation of biodiversity in N-limited grasslands.

\section{LITERATURE CITED}

Augustine, D. J., and D. A. Frank. 2001. Effects of migratory grazers on spatial heterogeneity of soil nitrogen properties in a grassland ecosystem. Ecology 82:3149-3162.

Augustine, D. J., S. J. McNaughton, and D. A. Frank. 2003. Feedbacks between soil nutrients and large herbivores in a managed savanna ecosystem. Ecological Applications 13:1325-1337.

BLAIR, J. M. 1997. Fire, N availability, and plant response in grasslands: a test of the transient maxima hypothesis. Ecology 78:2359-2368.

Bourlier, B. G., W. J. Ringwald, P. J. Workman, and S. Clemmons. 1979. Soil survey of Osage County, Oklahoma. US Department of Agriculture-Natural Resource Conservation Service.

Caldwell, M. M., J. H. Richards, D. A. Johnson, R. S. Nowak, and R. S. Dzurec. 1981. Coping with herbivory - photosynthetic capacity and resource-allocation in 2 semi-arid agropyron bunchgrasses. Oecologia 50:14-24.

CoLııns, S. L. 1990. Introduction: fire as a natural disturbance in tallgrass prairie. In: S. L. Collins and L. L. Wallace [EDS.]. Fire in North American tallgrass prairies. Norman, OK: University of Oklahoma Press. p 3-7.

ColuINS, S. L. 2000. Disturbance frequency and community stability in native tallgrass prairie. American Naturalist 155:311-325.

Coluins, S. L., and E. M. Steinauer. 1998. Disturbance, diversity, and species interactions in tallgrass prairie. In: A. K. Knapp, J. M. Briggs, D. C. Hartnett, and S. L Collins [EDS.]. Grassland dynamics: Long-term ecological research in tallgrass prairie. New York, NY: Oxford University Press. p 140-156.

DetLing, J. K., M. I. DyeR, AND D. Winn. 1979. Net photosynthesis, root respiration and regrowth of Bouteloua gacilis followed simulated grazing. Oecologia 45:26-31.

DigGs, G. M., B. L. Lipscomb, And R. J. O'Kennon. 1999. Shiners \& Mahler's illustrated flora of north central Texas. Ft. Worth, TX: Botanical Research Institute of Texas and Austin College.

Frank, D. A., And R. D. Evans. 1997. Effects of native grazers on grassland N cycling in Yellowstone National Park. Ecology 78:2238-2248.

Frank, D. A., R. S. Inouye, N. Huntly, G. W. Minshall, and J. E. Anderson. 1994. The biogeochemistry of a north-temperate grassland with native ungulatesnitrogen dynamics in Yellowstone-National-Park. Biogeochemistry 26:163-188.

Frank, D. A., And S. J. McNaughton. 1992. The ecology of plants, large mammalian herbivores, and drought in Yellowstone-National-Park. Ecology 73: 2043-2058.

Frank, D. A., and S. J. McNaughton. 1993. Evidence for the promotion of aboveground grassland production by native large herbivores in YellowstoneNational-Park. Oecologia 96:157-161.

Funlendorf, S. D., AND D. M. Engle. 2001. Restoring heterogeneity on rangelands: ecosystem management based on evolutionary grazing patterns. Bioscience $51: 625-632$

Funlendorf, S. D., And D. M. Engle. 2004. Application of the fire-grazing interaction to restore a shifting mosaic on tallgrass prairie. Journal of Applied Ecology 41:604-614. 
Fuhlendorf, S. D., W. C. Harrell, D. M. Engle, R. G. Hamilton, C. A. Davis, and D. M. LESLIE, JR. 2006. Should heterogeneity be the basis for conservation? Grassland bird response to fire and grazing. Ecological Applications 16(5):1706-1716.

Fynn, R. W. S., R. J. HAYNeS, AND T. G. O'Connor. 2003. Burning causes long-term changes in soil organic matter content of a South African grassland. Soil Biology and Biochemistry 35:677-687.

Goncalves, J. L. M., And J. C. Carlyle. 1994. Modeling the influence of moisture and temperature on net nitrogen mineralization in a forested sandy soil. Soil Biology and Biochemistry 26:1557-1564.

HoвBs, N. T. 1996. Modification of ecosystems by ungulates. Journal of Wildlife Management 60:695-713.

Jansen, R., R. M. Little, and T. M. Crowe. 1999. Implications of grazing and burning of grasslands on the sustainable use of francolins (Francolinus spp.) and on overall bird conservation in the highlands of Mpumalanga province, South Africa. Biodiversity and Conservation 8:587-602.

Johnson, L. C., AND J. R. Matchett. 2001. Fire and grazing regulate belowground processes in tallgrass prairie. Ecology 82:3377-3389.

Knapp, A. K., J. M. Blair, J. M. Briggs, S. L. Collins, D. C. Hartnett, L. C. Johnson, AND E. G. Towne. 1999. The keystone role of bison in north American tallgrass prairie-bison increase habitat heterogeneity and alter a broad array of plant, community, and ecosystem processes. Bioscience 49:39-50.

Maron, J. L., and R. L. JefFries. 2001. Restoring enriched grasslands: effects of mowing on species richness, productivity, and nitrogen retention. Ecological Applications 11:1088-1100.

MatTson, W. J. 1980. Herbivory in relation to plant nitrogen content. Annual Review of Ecology and Systematics 11:119-161.

McNaughton, S. J. 1984. Grazing lawns-animals in herds, plant form, and coevolution. American Naturalist 124:863-886.

McNaughton, S. J., F. F. Banyikwa, and M. M. McNaughton. 1997. Promotion of the cycling of diet-enhancing nutrients by African grazers. Science 278:17981800.

McNaughton, S. J., F. F. Banyikwa, and M. M. McNaughton. 1998. Root biomass and productivity in a grazing ecosystem: the Serengeti. Ecology 79:587-592.

McNaughton, S. J., R. W. Ruess, and S. W. Seagle. 1988. Large mammals and process dynamics in African ecosystems. Bioscience 38:794-800.

Milchunas, D. G., and W. K. Lauenroth. 1993. Quantitative effects of grazing on vegetation and soils over a global range of environments. Ecological Monographs 63:327-366.

Milchunas, D. G., and W. K. Lauenroth. 1995. Inertia in plant community structure-state changes after cessation of nutrient-enrichment stress. Ecological Applications 5:452-458.

MulvaneY, R. L. 1996. Nitrogen-inorganic forms. In: D. L. Sparks [ED.]. Methods of soil analysis. Part 3. Chemical methods-Book Series 5. Madison, WI: Soil Science Society of America. p 1123-1184.
OJima, D. S., D. S. Schimel, W. J. Parton, and C. E. Owensby. 1994. Long-term and short-term effects of fire on nitrogen cycling in tallgrass prairie. Biogeochemistry 24:67-84.

Oscarson, P., T. Lundborg, M. LaRsson, and C. M. Larsson. 1995. Fate and effects on yield components of extra applications of nitrogen on spring wheat (TriticumAestivum L) grown in solution culture. Plant and Soil 175:179-188.

Osterheld, M., and S. J. McNaughton. 1988. Interspecific variation in the response of Themeda triandra to defoliation: the effect of time of recovery and growth rates on compensatory growth. Oecologia 85:181-186.

Ostertag, R., AND S. E. HobBie. 1999. Early stages of root and leaf decomposition in Hawaiian forests: effects of nutrient availability. Oecologia 121:564-573.

Parton, W. J., D. S. Schimel, C. V. Cole, and D. S. OJima. 1987. Analysis of factors controlling soil organic-matter levels in great-plains grasslands. Soil Science Society of America Journal 51:1173-1179.

Risser, P. G., AND W. J. PARTon. 1982. Ecosystem analysis of the tallgrass prairie: nitrogen cycle. Ecology 63:1342-1351.

Ruess, R. W., And S. J. McNaughton. 1987. Grazing and the dynamics of nutrient and energy regulated microbial processes in the Serengeti grasslands. Oikos 49:101-110.

Sankaran, M., And D. J. Augustine. 2004. Large herbivores suppress decomposer abundance in a semiarid grazing ecosystem. Ecology 85:1052-1061.

SAS/STAT [computer program]. 1989. Version 6. Cary, NC: SAS Institute Inc.

Schimel, D. S., AND W. J. PARTon. 1986. Microclimatic controls of nitrogen mineralization and nitrification in shortgrass steppe soils. Plant and Soil 93:347-357.

Seagle, S. W., S. J. McNaughton, and R. W. Ruess. 1992. Simulated effects of grazing on soil-nitrogen and mineralization in contrasting Serengeti grasslands. Ecology 73:1105-1123.

Seastedt, T. R., J. M. Briggs, and D. J. Gibson. 1991. Controls of nitrogen limitation in tallgrass prairie. Oecologia 87:72-79.

Seastedt, T. R., and A. K. Knapp. 1993. Consequences of nonequilibrium resource availability across multiple time scales-the Transient Maxima hypothesis. American Naturalist 141:621-633.

Steuter, A. A., E. M. Steinauer, G. L. Hill, P. A. Bowers, and L. L. Tieszen. 1995. Distribution and diet of bison and pocket gophers in a sandhills prairie. Ecological Applications 5:756-766.

TILMAN, D. 1987. Secondary succession and the pattern of plant dominance along experimental nitrogen gradients. Ecological Monographs 57:189-214.

Towne, E. G., AND K. E. Kemp. 2003. Vegetation dynamics from annually burning tallgrass prairie in different seasons. Journal of Range Management 56:185-192.

Tracy, B. F., and D. A. Frank. 1998. Herbivore influence on soil microbial biomass and nitrogen mineralization in a northern grassland ecosystem: Yellowstone National Park. Oecologia 114:556-562.

Turner, C. L., J. M. Blair, R. J. Schartz, and J. C. Neel. 1997. Soil N and plant responses to fire, topography, and supplemental $\mathrm{N}$ in tallgrass prairie. Ecology 78:1832-1843. 